OPEN ACCESS

Edited by:

Laura McPherson,

Dartmouth College, United States

Reviewed by:

Samuel Kayode Akinbo,

University of British Columbia, Canada

Olabode Omojola,

Mount Holyoke College, United States

*Correspondence:

Mariano González

m.gonzalez@uu.nl

Specialty section:

This article was submitted to

Language Sciences,

a section of the journal

Frontiers in Communication

Received: 12 January 2021 Accepted: 05 November 2021

Published: 21 February 2022

Citation:

González M and Oludare O (2022) The Speech Surrogacy Systems of the Yoruba Dùndún and Bàtá Drums. On

the Interface Between Organology

and Phonology.

Front. Commun. 6:652542.

doi: 10.3389/fcomm.2021.652542

\section{The Speech Surrogacy Systems of the Yoruba Dùndún and Bàtá Drums. On the Interface Between Organology and Phonology}

\author{
Mariano González ${ }^{1 *}$ and Olupemi Oludare ${ }^{1,2}$ \\ ${ }^{1}$ Utrecht Institute of Linguistics UiL OTS, Utrecht University, Utrecht, Netherlands, ${ }^{2}$ UNILAG, University of Lagos, \\ Lagos, Nigeria
}

This paper explores the interdependence between organology and phonology in the Yoruba dùndún and bàtá drums. We analyze how the specific features of these drums, such as corpus shape, size, kind and number of membranes, and playing techniques affect their systems of speech surrogacy. The study relies on field recordings collected by the authors in Lagos, Nigeria, in February 2020, featuring drummed performances of Yoruba sentences previously unknown to the informants. The recorded sentences were transcribed and analyzed comparatively, which allows us to characterize systematic regularities in the speech-to-drum mapping. Observing how the intrinsic characteristics of language sounds (pitch, duration, intensity and spectrum) are addressed by means of the organologic and acoustic properties of the dùndún and the bàtá, we conclude that these drums' different properties foster distinct speech surrogacy systems. Alongside a consideration of native perspectives on speech surrogacy, we propose an understanding of drum languages as platforms capable of supporting the development of native theories on sound and language.

Keywords: drum languages, speech surrogacy, bàtá, dùndún, Yoruba, drum music, organology

\section{INTRODUCTION}

This paper presents the current state of an ongoing investigation into the speech surrogacy systems of the dùndún and bàtá drums of the Yoruba people in Southwestern Nigeria. Used for communication in a series of daily situations, as well as in civic and religious rituals, the dùndún and bàtá drums are capable of mimicking the spoken Yoruba language, thus being popularly referred to, both in Nigeria and abroad, as "talking drums."

The main focus of interest of the investigations resides in the fact that the dùndún and bàtá drums, besides playing distinct cultural roles in the Yoruba community, are very different instruments, and are related to the spoken language in different ways, yet still fulfill a similar function as "talking" drums, or speech surrogates (Beier, 1954; Arewa and Niyi, 1980; Euba, 1990; Klein, 2000; Ruskin, 2013; Oludare, 2020, 2021, and others). On a cultural level, the bàtá and dùndún differ largely on their contextual applications, as well as on their traditional and religious customs. While the bàtá is generally regarded as a religious instrument protected by specific ritual codes of the orisá devotion, the dùndún is present both in diverse religious settings, as well as in urban popular music. On a musical level, these drums have different tuning systems, number and kind of membranes, as well as varied playing techniques. Each of them displays its own phonological system, which is related to the 
Yoruba language based on distinct parameters. The present study aims at comparing the linguistic usages of the bàtá and dùndún. This is done by studying the regularities found in the mapping between Yoruba phonology and the speech surrogacy practices on the two drums. To this end, we analyze how drummers make use of the specific features of their instruments when performing texts, and which general rules can be identified in the translation from a spoken utterance to a drummed utterance.

Like most African languages, Yoruba is a tonal language, where pitch variations distinguish lexical entries and grammatical processes (Pulleyblank, 2004; Ajiboye, 2011). Yoruba has three relative pitches - Low, Mid and High known as ohùn isàlè, àárín, and òkè in Yoruba terminology. In present-day Nigeria, the three Yoruba speech tones are more commonly referred to as Do, Re and Mi, respectively. These terms are inspired by Western music theory, yet with no particular relation to their conventional frequencies or interval ratios. Additionally, the Yoruba speech tone system is characterized by a series of glides connecting these three basic pitches.

The studied drums display distinct organological features that determine how they are used in rendering Yoruba speech. The dùndún drums are flexible tension drums, and are used mostly to imitate the tonal inflections of Yoruba, with three tones, or pitches, and different glides between them. At present, two types of dùndún drums are used regularly: iyáàlù dùndún and the gángan. These two types of the dùndún share the same basic construction, and differ mostly in size, with the gángan being about half the size of the iyáàlù dùndún. Unlike the dùndún, bàtá drums have fixed membranes: two on the iyáàlu bàtá and three (playable) on the omele bàtá. The different membranes may be played simultaneously, or separately from one another.

Most actual performances with dùndún and bàtá drums involve a traditional repertoire of texts, including praise poetry (oríki) and proverbs (òwe). However, the musicians are capable of drumming any given text in Yoruba. This paper concentrates on this trait. Our aim is to contribute to the on-going formal description of these speech surrogates (Oyelami, 1989, Euba, 1990 and 2011, Villepastour, 2010, and Akinbo, 2019), by comparing the way in which previously unknown sentences are played on the four types of drums we study.

The research is based on a collection of 12 sentences in Yoruba as performed on the iyáàlù dùndún (Mr. Ayanlere Alajede), gángan (Mr. Kangan Bamidele), iyáálù bàtá and omele bàtá ${ }^{1}$. Each drummer was asked to perform the sentences on his instrument. The sentences, previously unknown to the drummers, were composed by the researchers and display varied phrasal structures and vocabulary, and were read out loud to the drummers by a native speaker in the moment of recording. The drummers were allowed to take some time, if necessary, to internalize the sentences before playing them on their drums, but, with the exception of some of the longer sentences, most of the drummers responded immediately after the linguistic stimuli. Each sentence was recorded in three

${ }^{1}$ Our main bàtá informant, a master drummer from Àyán tradition, requested to remain anonymous. rhythmically distinct versions. The first of them corresponds to what was characterized by Akin Euba (1990) as "speech mode," i.e., without a specific rhythmic background the drummer has to relate to. In the second and third versions, the drummers were requested to perform the same sentences in the "dance mode" (ibid.), which matches two common rhythmic accompaniments, with both 16- and 12-pulse time-line patterns (Kubik, 2008).

The recordings were transcribed and annotated. This was used to identify how different drummers, using distinct instruments in various (musical and linguistic) situations, transfer the linguistic data to a drummed equivalent, and what techniques they use in doing so. The results were used for comparing the speech surrogacy systems supported by the four instruments.

By means of a side-by-side comparison of the dùndún and bàtá speech surrogacy systems, we focus on similarities between distinct drum sounds, and the sounds of language. For this reason, beyond exploring the mapping between units of speech and drum sounds, we stress the acoustic ground on which this system relies, and how humans perceive these sounds. For that, we use both spectrograms - as an objective tool for the visualization and analysis of sound phenomena - and fragments of interviews with Yoruba musicians, who describe, by means of their own knowledge and sensibility, how the sounds of the drums they play relate to the sounds of the language they speak.

\section{THE DÙNDÚN SPEECH SURROGACY}

The Yoruba dùndún drums are hourglass-shaped bimembranophones manufactured in distinct sizes. Here, we concentrate on the gángan and on the iyáàlù dùndún, whose basic construction is the same. In a traditional dùndún ensemble, the iyáàlù takes the leading role and is responsible for most textbased passages.

The dùndún ensemble comprises at least five instruments, belonging to three sub-families: 1) the iyáàlù sub-family, consisting of the iyáàlù-the "mother drum," leader of the ensemble, as well as the keríkeri, isáájú, and ikehin; 2) the gángan sub-family, consisting of the gángan, the àdàmò (often called "gángan" too; see below), and the kànàngó; and 3) the gúdúgúdú sub-family, which only has one type of drum. The instruments of the iyáàlù and gángan families are all tension drums in distinct sizes, whereas the gúdúgúdú is a kettle (nontension) drum.

Sometimes, two iyáàlù drums may be engaged in the ensemble, with the second referred to as the èjin, providing an effect of a two-tone bass melo-rhythmic pattern. While the iyáàlù, gudugudu, keríkerì, isáájú, and ikehìn are the standard drum members of dùndún ensembles, any one or all of the gángan, àdàmò, and kànàngó may also be included in the ensemble, often duplicating one of the keríkeri, isáájú, and ikehin drums, as required by the musical performance (King, 1961; Adegbite, 1988; Euba, 1990; Olaniyan, 2008; Oluga and Babalola, 2012; Osundina, 2015; Olatunji, 2017; Oludare, 2018). It is important to note that the traditional name "gángan" is now used interchangeably for two different drums. According to Kangan 
Bamidele and Ayanlere Alajede (personal communication on February 3, 2020), the àdàmò is now referred to as the gángan, which is ubiquitous in the urban settings, favored among young drummers, and adopted in popular and gospel music. In the present paper, we opted to use this current terminology.

The attachment and tuning of the membranes are achieved in the dùndún drums using multiple cords made from animal skin, which are fastened on the flexible rims surrounding the membranes, and connect the two membranes to each other without contact to the wooden corpus of the drum. The drums are carried horizontally on the musician's shoulder with a strap and played with the curved stick opá, a wooden beater in "J" form. The bigger iyáàlù drum is carried on the height of the musician's waist, while the (smaller) gángan is carried in a similar way to a purse, under the axil. The player of the iyáàlù dùndún embraces some of the tuning cords of the drum with the left hand ${ }^{2}$, thus they can increase or release the tension of the membranes by squeezing the drum between their fingers and against their waist. On the gángan, a similar technique applies, but with the drum being compressed between the drummer's upper arm and ribs. The left hand of the gángan player is kept on the upper side of the drum's rim. On this instrument, also the fingertips and nails of the left hand are used to provide percussive sounds and to mute the drum membrane (when required) in-between drum strokes.

This flexible tuning mechanism, combined with the unique fashion in which each of the drums is carried, allows drummers to vary the tension of the membranes continuously by applying more or less pressure to the tuning cords, which affects the drum's pitch. Players use this technique to imitate the three basic Yoruba tones, as well as the tone inflections that occur on rising or falling gliding tones or between syllables of distinct tones.

Playing the dùndún drums involves an interplay between the opá strokes and changes in the membrane tension. Before striking the membrane, the drummer can adjust the membrane to three basic levels of tension: a loosened stage, without applying any tension to the membrane (producing a low pitch that mimics the low speech tone); a half-way tensioned stage, applying some pressure on the tuning cords (mid speech tone); or a tight stage, when full pressure is applied (high speech tone). After striking the membrane, the drummer can make further modifications to the tuning of the instrument, causing the pitch to rise or fall while the membrane continues to vibrate. This generates gliding pitches that are used to imitate the tonal inflections used in Yoruba speech. Describing this interplay requires isolating single units of action within a sequence of strokes and movements, which we have achieved using the annotation method described below.

\section{The Dùndún Phonology}

In his comprehensive work on the dùndún drums, Akin Euba (1990) did not have access to the use of spectrograms or any other technology that would facilitate a detailed description or graphic

${ }^{2}$ All references to the handedness of playing techniques in the present text describe the most common practice for right-handed drummers. There can be differences between individual players. visualization of the nuances of intonation of the dùndun drums. Due to these technical limitations, this aspect of the dùndún phonology is treated only in a rather rudimentary way in his transcriptions and analysis. Akinbo (2019) takes an initial crucial step into filling this gap, describing a range of distinct possibilities of tonal inflections that can be performed on a dùndún drum to represent short words of one or two syllables. The present work contributes to the study of the dùndún phonology by describing the regularities found in the ways dùndún playing techniques are used to render diverse phonological aspects of Yoruba in longer, varied sentences, largely relying on detailed annotation of spectrograms.

Representing the recordings in spectrograms allows us to isolate the opá stroke (or onset) and the sustained sound produced by the vibrating membrane, thus facilitating the description of the sounds used in the course of a dìndún performance. On a spectrogram, each stroke appears as a vertical line crossing the whole image. This is due to the fact that the impact of the drum-stick on the skin produces a fair amount of "noise" (diffused sound frequencies), which decays within a very short period of time. Immediately after the onset, the vibrating membrane emits a clearly defined pitch, which can be read on the spectrogram as a horizontal line or as a curve, varying according to the tension applied to the membrane by the player. Accordingly, the spectrogram of a dundún performance contains data on 1) the moment of impact of the opá, 2) the initial pitch of the sound, 3 ) the tuning, i.e., tension variations of a sound, including the moment and rate these variations take place, as well as 4) the intensity (amplitude) and 5) the overall duration of a sound.

Figure 1 shows the spectrogram for an iyáàlù dùndún rendition of the sentence "Bàbá àgbàlagbà kaán jókòó lórí àga pupa" ("There is an old man sitting on a red chair"). With a few exceptions, which will be commented on later, each syllable corresponds to one stroke (vertical line) and the subsequent horizontal line or curve to its right.

The shape of each of these lines and curves can be described by observing how the pitch is caused to rise, fall or stagnate as a result of changes in the membrane tension. The sounds produced by a dùndún drum can thus be annotated as sound shapes resulting from a sequential combination of specific movements of both arms, and in direct correlation with the phonemes of the Yoruba language. Each of these shapes, as described in the example below, contains precise information on the kind, intensity and speed of the left-arm movements related to the tuning of the membrane, as well as the moment in time in which the opá strokes and arm movements take place.

Table 1 describes examples for the annotation of spectrogram shapes encountered on dùndún performances and their mapping to the corresponding playing techniques and the spoken syllables they represent. Each shape is formed by one or more vertical lines, indicating the moment of onset (impact of the opá on the membrane), and one or more lines or curves indicating the course of the sound with its pitch variations.

The column "playing technique" indicates the initial stage of the membrane (loosened, half-way tight or tight), the position of each stroke (Pos. 1 = first action), and the presence $(+)$ or absence $(-)$ of movement (pressure increase/release/oscillation) and its 


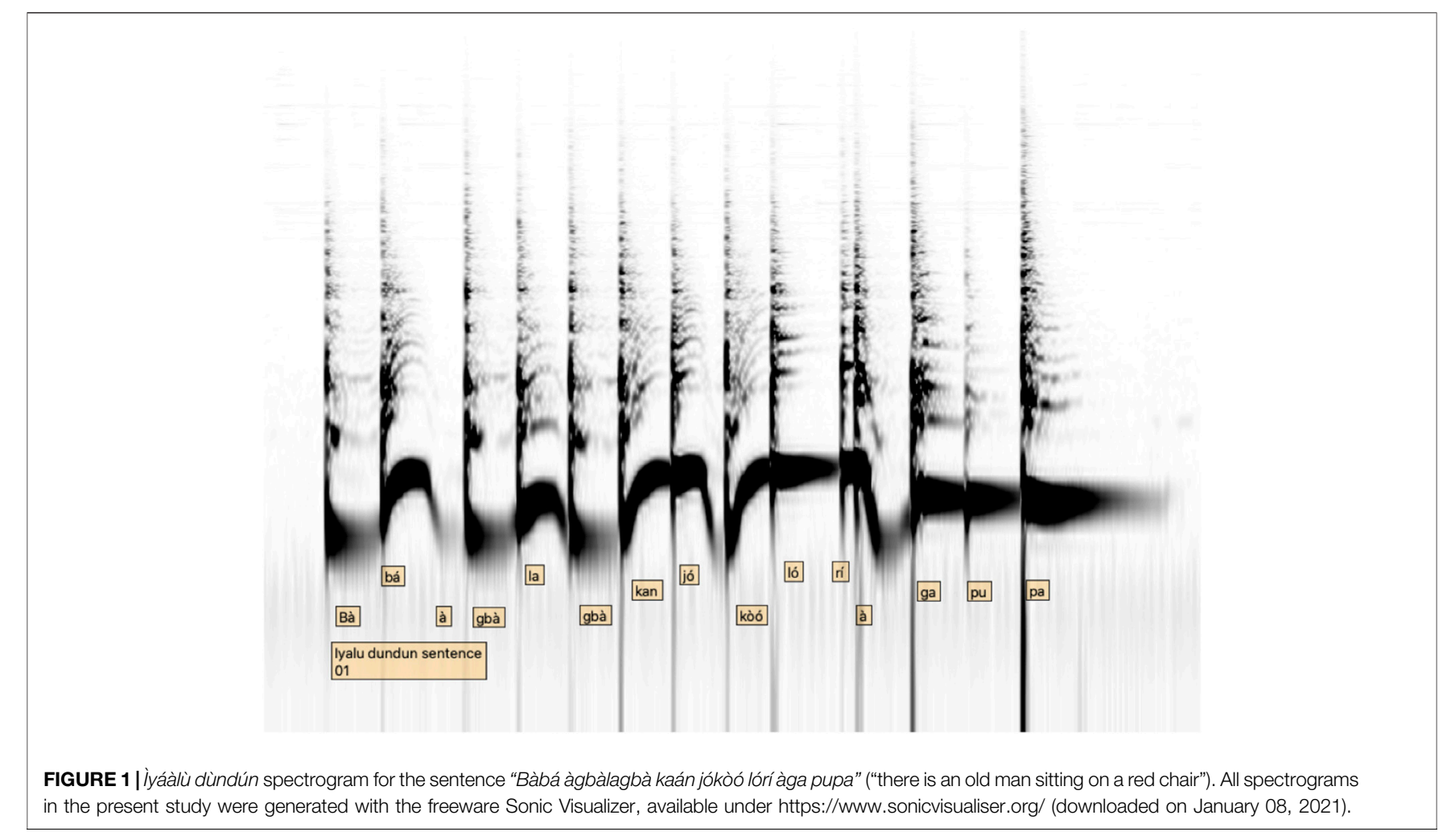

TABLE 1 | The phonology of the dùndún. The black shapes on the spectrogram images were manually added by the researchers to facilitate reading.

\begin{tabular}{|c|c|c|c|c|c|}
\hline $\begin{array}{l}\text { Spectrogram } \\
\text { shape }\end{array}$ & Playing technique & Acoustic resultant & Phonological meaning & Notation & Example \\
\hline & $\begin{array}{l}\text { Membrane: loosen } \\
\text { Pos. 1: strike (-) movement }\end{array}$ & Sound on low pitch & Syllable on low tone (do) & [do] & Bàbá \\
\hline & $\begin{array}{l}\text { Membrane: half-way tight } \\
\text { Pos. 1: strike (-) movement }\end{array}$ & Sound on mid pitch & Syllable on mid tone (re) & [re] & Àga \\
\hline & $\begin{array}{l}\text { Membrane: tight } \\
\text { Pos. 1: strike (-) movement }\end{array}$ & Sound on high pitch & Syllable on high tone (mi) & [mi] & Lórí \\
\hline
\end{tabular}


TABLE 1 | (Continued) The phonology of the dùndún. The black shapes on the spectrogram images were manually added by the researchers to facilitate reading

\begin{tabular}{|c|c|c|c|c|c|}
\hline $\begin{array}{l}\text { Spectrogram } \\
\text { shape }\end{array}$ & Playing technique & Acoustic resultant & Phonological meaning & Notation & Example \\
\hline & $\begin{array}{l}\text { Membrane: half-way tight } \\
\text { Pos. 1: strike }(+) \text { movement: } \\
\text { oscillation up-down }\end{array}$ & Sound on mid pitch with oscillation & Syllable on mid tone (re) & [re $]$ & àgbàlagbà \\
\hline & $\begin{array}{l}\text { Membrane: tight } \\
\text { Pos. 1: strike (-) movement } \\
(+) \text { movement: pressure release: } \\
\text { quick }\end{array}$ & $\begin{array}{l}\text { Sound on high pitch dropped after } \\
\text { sounding }\end{array}$ & Syllable on high tone before syllable on low tone & {$[\mathrm{mi} \mathrm{V}]$} & Jókòó \\
\hline & $\begin{array}{l}\text { Membrane: loosen } \\
\text { Pos. 1: strike (+) movement: } \\
\text { pressure increase: quick } \\
\text { (+) movement: pressure release: } \\
\text { quick }\end{array}$ & $\begin{array}{l}\text { Upwards glide followed by } \\
\text { downwards glide }\end{array}$ & $\begin{array}{l}\text { Syllable on high tone followed by syllable on low } \\
\text { tone on the same vowel (diphthong) }\end{array}$ & $\begin{array}{l}{[\wedge} \\
\text { mi] (vdo) }\end{array}$ & Bàbá àgbà \\
\hline & $\begin{array}{l}\text { Membrane: loosen } \\
\text { Pos. 1: strike (+) movement: } \\
\text { pressure increase: slow }\end{array}$ & $\begin{array}{l}\text { Sound on low pitch followed by } \\
\text { upwards glide }\end{array}$ & $\begin{array}{l}\text { Syllable on low tone followed by syllable on high } \\
\text { tone on the same vowel }\end{array}$ & [do] $(\wedge \mathrm{mi})$ & Jókòó \\
\hline & $\begin{array}{l}\text { Membrane: tight } \\
\text { Pos. 1: strike }(-) \text { movement } \\
\text { Pos. 2: strike }(+) \text { movement: } \\
\text { pressure release: slow }\end{array}$ & $\begin{array}{l}\text { Double stroke on high pitch } \\
\text { followed by downwards glide }\end{array}$ & $\begin{array}{l}\text { "quick" syllable on high pitch followed by syllable } \\
\text { on low tone }\end{array}$ & {$[(\mathrm{mi})(\mathrm{vdo})]$} & Lórí àga \\
\hline
\end{tabular}

rate (slow or quick) with the left arm of the player. These shapes and their classification form a basic repertoire of sound units that can be used to describe and compare dùndún performances of speech texts, with every shape corresponding to one or sometimes two syllables. The columns "acoustic resultant" and "phonological meaning" describe how each drum sound is perceived acoustically and how it is related to the sounds of spoken Yoruba.

The "notation" column represents drum sounds with minimal number of symbols, as follows:

- The notes do, re and mi refer respectively to the low, mid and high tones of Yoruba speech as used conventionally today by Yoruba speakers in allusive manner, without any correspondence to the actual pitches or interval ratios they represent in Western music theory.

- The symbols $\wedge$ and $\vee$ placed before a tone name signalize that the tone in question was reached through an up- or downwards glide, respectively.

- The symbols $\wedge$ and $\vee$ placed after a tone name signalize an up- or downwards glide after the tone in question.

- The symbol $\sim$ represents a pitch oscillation.

- The square brackets [] indicate that the sound between them was produced by a strike with the playing stick opá.

- The round brackets () indicate that the sound between them was concatenated to the previous sound through a glide without a new opá strike immediately before it. 
- Double strokes, produced by the rapid re-bounce of the opá stick, are represented as e.g., [re re] or [re mi].

Departing from the description of the shapes seen above, it is possible to establish a generative model, or finite state machine, describing how each membrane tension stage is assigned to one Yoruba speech syllable in the dùndún speech surrogacy, as well as how single tension stages can be concatenated between strokes, rendering the intonational glides of Yoruba speech.

In the model above (Figure 2), the $\mathrm{L}, \mathrm{M}$ and $\mathrm{H}$ states represent the different levels of membrane tension, which are related to the three tones of Yoruba speech, commonly referred to as do, re and mi, respectively. The arrows represent the possible transitions from one tension state to another or the permanence on one state, as a result of the increase, decrease or maintenance of the pressure applied by the player's left arm and hand to the tuning cords. The transitions are annotated according to their interpretation in Yoruba speech and identified with the help of a number and letter combination (1a, 2a etc.). Each sound is understood as the transition or the concatenation of transitions occurring after a stroke and before the next stroke. Normally, not more than two transitions are concatenated, due to the limited duration of the audible vibration of the membrane.

Through a nuanced stick playing technique, the player of the iyáàlù dùndún is also able to take vowel intrinsic intensity into account when modulating the force with which the membrane is hit (Villepastour, 2010, p. 83). On the amplitude wave in Figure 3, it is noticeable that the syllables containing the vowels high vowels $/ \mathrm{i} /$ and $/ \mathrm{u} /$ are played in a significantly softer manner (lower amplitude), when compared to the surrounding strokes.

This tendency can be observed throughout the analyzed data, even there, where achieving this contrast in amplitude demands a complex playing technique. In the beginning of the double strokes "sí ojà" and "mi ra", shown on Figure 4, the achievement of the contrast between soft and strong strokes requires the first attack of each double or re-bouncing stroke to be played softer than the second attack, which means that the player must skillfully increase the beater's energy between both strokes within a very short time frame.

Although the representation of vowel height is present throughout the iyáàlù dùndún data that we collected, it should be pointed out that it is not necessarily recognized by the artists. Our main informant for the iyáàlù dùndún, Mr. Ayanlere Alajede, a prestigious senior dùndún master drummer, suggested that vowel height is not part of the iyáàlù dùndún speech surrogacy. For him, this practice relies solely on the reproduction of the pitch component of Yoruba speech. Evidently, the relation between vowel height and amplitude cannot be expected to be consciously perceived by any speaker

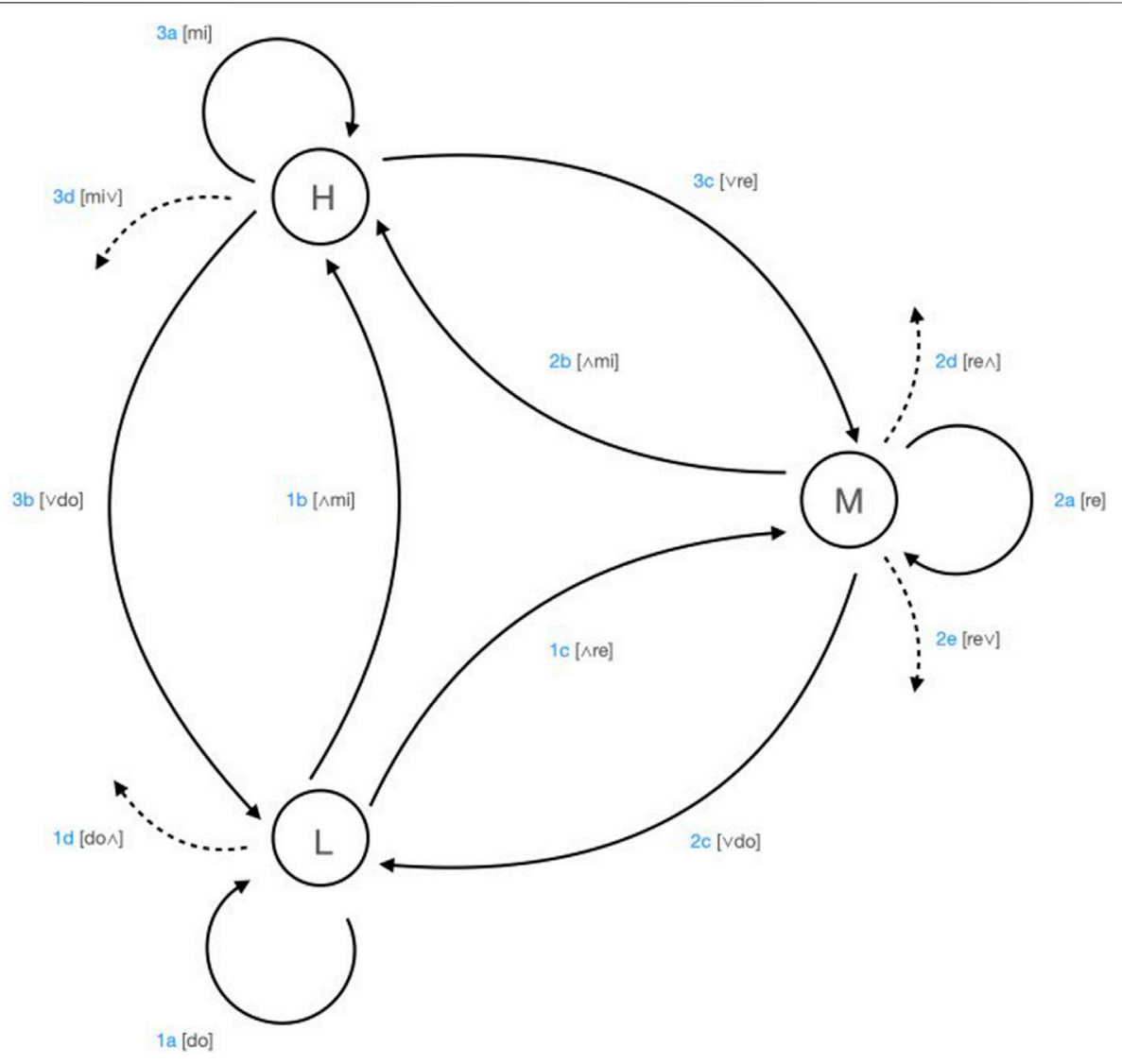

FIGURE 2 | Graphic representation of the dùndún speech surrogacy system as a finite state machine. 


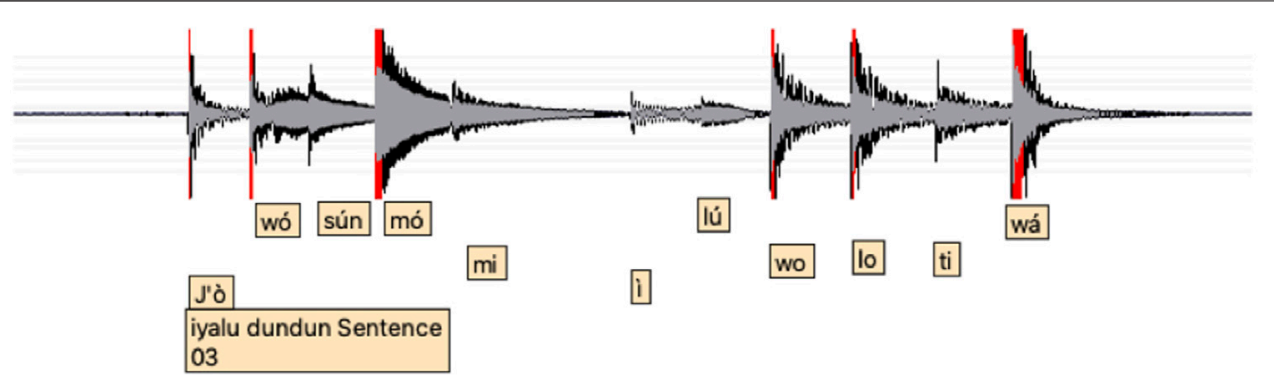

FIGURE 3 | lyaáàlù dùndún amplitude wave for the sentence "J'òwó sún mó mi. lilú we lo ti wá" ("Please come here. Where are you from?").

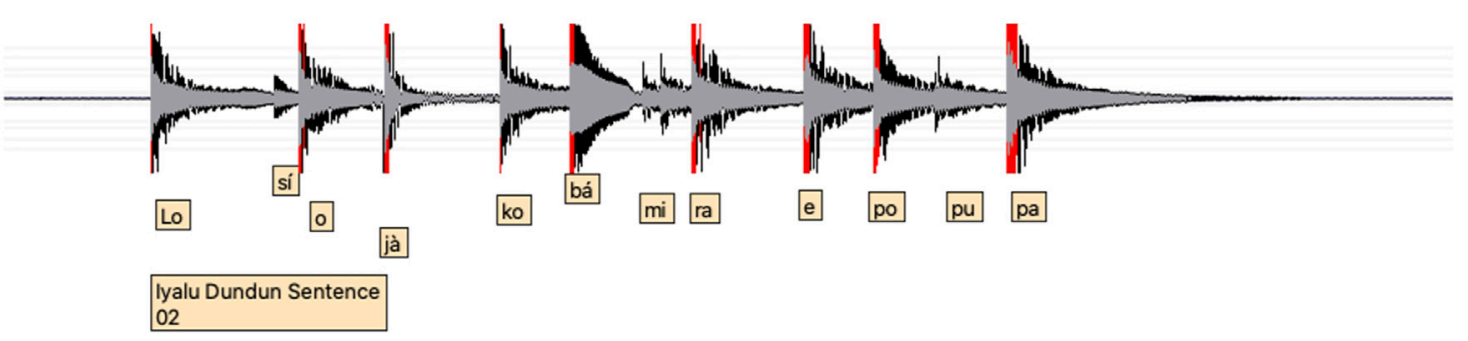

FIGURE 4 | lyáàlù dùndún amplitude wave for the sentence "Lo sí ojà k'o bámi ra epo pupa" ("Go to the market and buy me palm oil”).

of any natural language, as this relation is hardly conceived without means for acoustic measurement. The relation between vowel height and amplitude can be considered as an acoustic by-product of vowel intrinsic intensity ${ }^{3}$, rather than a phonological distinction. The fact that the imitation of speech by highly skilled drummers is sensitive to such relations gives us a hint as to the extent to which "talking" and "drumming" are kept close by masters of this craft.

The gángan, apart from being smaller in size than the iyáàlù dùndún, features the same construction elements and a similar playing technique. The most relevant differences between the two drums, as seen in our dataset, concern the glides and the rendering of the $/ \mathrm{r} /$ consonant, present to a lesser extent on the gángan, as well as the differentiation between high and nonhigh vowels by means of amplitude, absent on our gángan recordings. The absence of these traits on the gángan speech surrogacy can be tracked back mostly to the cultural context of this instrument in present-day urban Nigeria. According to Kangan Bamidele (personal communication on February 4, 2020), most gángan players today only learn the instrument in an urban environment, thus learning only the necessary playing techniques required to apply the drum in the orin àsikò (popular music) or igbàlódé (modern music) settings. Ayanlere Alajede also argues that, while rendering intonational glides and the /r/ consonant should be regarded as the most correct practice for all dùndún drums, including the gángan, the modern day gángan

${ }^{3}$ See the spectral analysis of Yoruba vowels in the discussion on bàtá vowel representations below. players often omit them due to their limited knowledge of the tradition. He added that only those who learn through the Ayan (Yoruba indigenous knowledge system of drumming) apprenticeship will know the àsà (culture) and ise (practice) of the drum, with regards to communicating in Yoruba Language and mastery of its full performance techniques (personal communication on February 4, 2020). Besides cultural aspects of performance context and apprenticeship, the small membrane size of the gángan can be regarded as an additional organological reason for the different speech surrogacy practices on the two studied dùndún drums. With a much shorter sustain time-the time during which the membrane keeps vibrating and sounding after a stroke - the gángan membrane is limited in its possibilities of performing glides, for which a long sustain time is advantageous. Equally, its small size imposes limitations on tuning and amplitude variations.

\section{THE ÌYÁÀLÙ BÀTÁ SPEECH SURROGACY}

\section{Organology}

The iyáàlù bàtá is a large sized (ca. $80 \mathrm{~cm}$ length) bimembranophone drum with a conic wooden corpus. The two membranes of the iyáàlù bàtá are of different sizes and are called ojú òjò, and sásá, with their diameters measuring around 35 and $20 \mathrm{~cm}$, respectively. The membrane attachment system of the bàtá drums consists of a net of animal skin ropes connecting both membranes to each other. Unlike the dùndún drum, the membrane attachment system of the instruments of the bàtá family is tightly tied to the 
drum corpus. As a result, the drummer is not able to adjust the drum's tuning on the go.

The traditional bàtá ensemble consists of the iyáàlù bàtá, the omele bàtá, and either the omele méji (omele ako and kúdi, tied together), or the omele méta (omele ako, kúdi, and àdàmò, also known as aféré, tied together). Like in the dùndún ensemble, a second iyáàlù might also be used to provide the èjin. Both the omele méji or omele méta are played by one person, and only one of the pairing is used in a bàtá ensemble (Oyelami, 1991; Villepastour, 2010; Omojola, 2012). According to Euba (2011), and corroborated by our informants, the omele méta is a recent development in the bàtá drumming tradition, in response to the wish to give the omele bàtá some liberty to perform independent of the iyáàlù. A third and different pitched drum was thus added, so the omele méta can imitate the three tones of the Yoruba language in achieving speech surrogacy, hence our choice of the omele méta over the omele méji for this study.

To achieve the desired deep sound of the ojú òjò, the large skin of the iyáàlù bàtá, a portion of a tuning paste called ida is stuck close to the center of the drum, forming a circle or a ring around $3 \mathrm{~mm}$ thick and $5 \mathrm{~cm}$ wide. This paste is usually kept on the membrane during storage, and drummers frequently make small adjustments on the shape, placement or even amount of paste applied to their drums, striving to achieve the desired sound.

The instrument is carried on the drummer's right shoulder in horizontal position in front of the player, approximately on the waist's height, with the large skin ojú òjò on the left, and the small skin sásá on the right side of the player. The playing technique of the iyáàlù bàtá is different for each membrane. The ojú òjo is played with the bare hand using a palette of three basic strokes described below. For the sásá, a flexible strap of dry animal skin called bílálà is used as beater.

The ojú òjò has the following playing techniques:

- Open tone: The four fingers of the flat (left) hand are held together, hitting the membrane evenly and close to the drum rim, bouncing back after the stroke. This allows the membrane to vibrate freely, revealing the fundamental frequency of its sound spectrum. This technique produces a low and sustained sound.

- Muted tone: This stroke is similar to the open tone described above, however, here the hand is maintained on the membrane after the stroke, muting the skin. With this technique, the membrane is not allowed to vibrate freely, cancelling the fundamental frequency of its sound spectrum and producing a muted sound with short sustain time.

- Slap: In this technique, the four fingers of the left hand are held slightly spread and hard, striking the skin towards its center, with the fingertips reaching the region covered by the ida paste. In this stroke, the membrane is muted both by the fingers and by the region around the palm of the hand. The combination of the whip-like finger technique and the large contact surface between the player's hand and the membrane creates a bright and short sound of high frequency spectrum.
The sásá is played with the bilálà using one single technique, in which the skin strip is embraced by the closed four fingers of the right hand and supported by the stretched thumb. The membrane is hit hard by the bilálà with a quick wrist or lower arm movement, producing a loud and high-pitched sound.

\section{Basic Rules of the Ìyáàlù Bàtá Speech Surrogacy}

On the iyáàlù bàtá, the Yoruba speech tones are generally rendered using the three playing techniques of the ojù òjò described above, with the open, mute and slap strokes rendering the low, mid and high tones, respectively.

The following general regularities of the iyáàlù bàtá speech surrogacy were first described by Muraina Oyelami (1992), and have been observed throughout our collected data with only rare exceptions:

1. The three ojú òjò sounds (open tone $\mathrm{O}$, mute tone $\mathrm{M}$ and slap S) are assigned to the three tones of Yoruba language (ohùn isàlè, àárín, and òkè, or do, re and $\mathrm{mi}$ ) when performing syllables containing the high vowels /i/ and /u/ (1a, 2a and 3a on Figure 5).

2. The simultaneous playing (represented by the double line) of the sásá stroke Sa and one of the ojú òjò sounds is assigned to the respective Yoruba tone when performing syllables containing the non-high vowels /a/, /e/, /ẹ/, /o/ and /o/, $(1,2 b$, and $3 b)$.

3. The sásá stroke, when performed alone, is assigned to the Yoruba tone $\mathrm{mi}$, represented here as $\mathrm{mi}^{*}$, and can appear in some situations described below (4a).

The sásá stroke has two functions: 1) as a vowel intensity marker, when performed additionally to an ojú ojò stroke; and 2) as a high pitch (mi), when performed alone. In specific situations shown below, this second function may overrule the first, when a high-pitched syllable is represented by the sásá stroke only, even on syllables that would by default be represented by a joint ojú ojò and sásá strokes.

On the iyáàlù bàtá, both membranes are attached to the two ends of the same conic corpus, thus connected to each other by the same air column. A clear pattern of resonation can be seen between both membranes, causing their frequency spectra to overlap and their sounds to blend in an optimal way. An aural interpretation of this phenomenon would be, that on intense vowels, the sásá is added as to enhance the high frequency spectrum of the ojú òjò sound.

Additionally to the rules above, the following situations have proven to appear on a consistent basis:

\section{Vowel sequences}

Most double vowel sequences in spoken Yoruba require an intonational continuity, or, in the case of $\mathrm{H}-\mathrm{L}$ and $\mathrm{L}-\mathrm{H}$ sequences, an intonational glide. When rendering such double vowel sequences on the iyáàlù bàtá, both the ojú òjò stroke of the high-pitched syllable and the (eventual) sásá stroke of the low or 


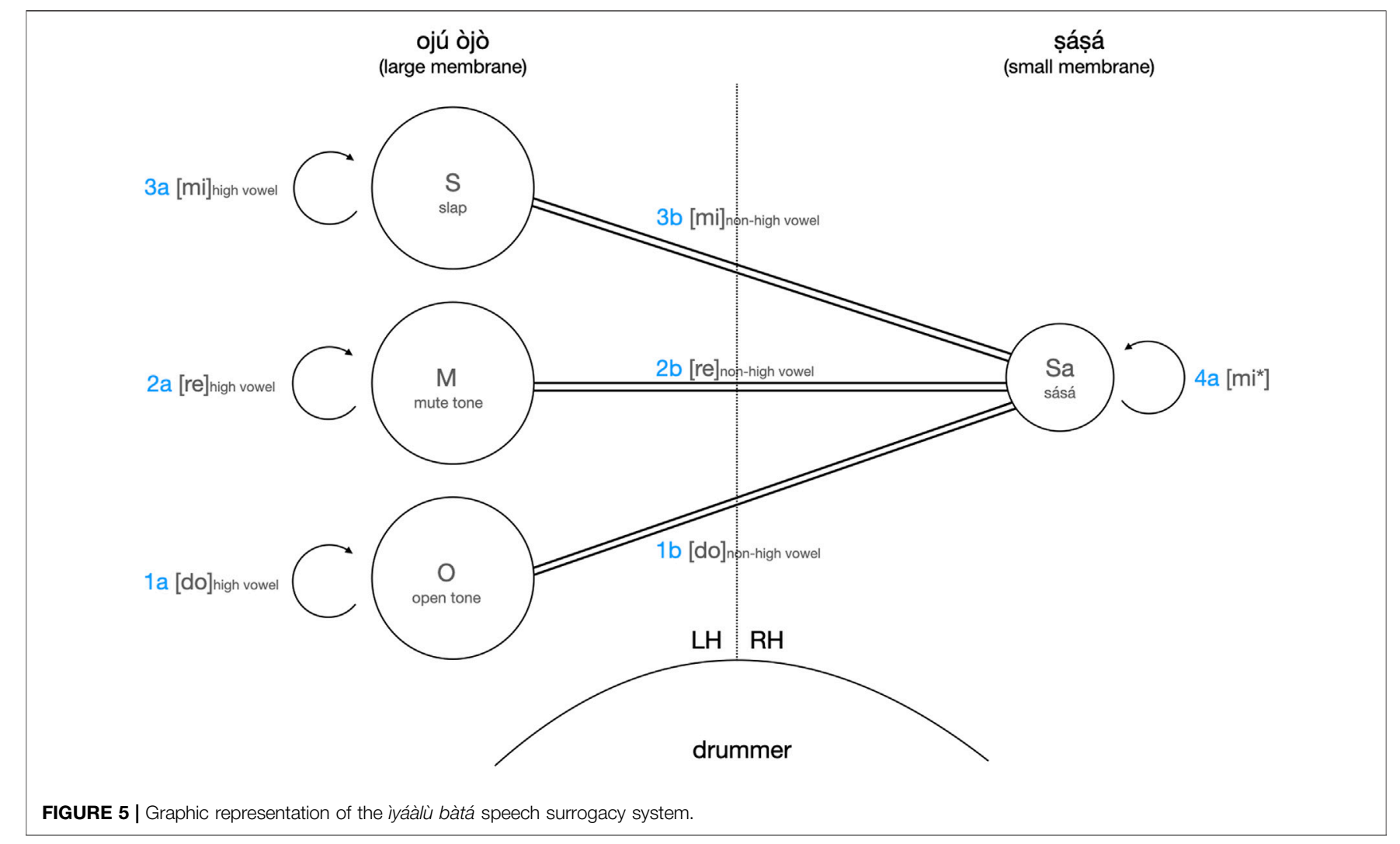

mid pitched syllable are left out. This can happen both in upwards (mid-high or low-high) sequences, as well in downwards (highmid and high-low) glides (Villepastour, 2010, p. 54).

\section{Contractions}

In spoken Yoruba, contractions between syllables and words are frequent, such as in $k i$ i-becoming $k o$. In these cases, drummers represented either the full expression or the contracted version. In one example, when asked to perform a sentence containing the contraction $k o$ in a sentence, as pronounced by the researcher, the drummer opted to perform the full expression $k i$, which requires two, instead of one single stroke. Following the handling of vowel sequences described above, the syllable $k i$ was performed on the sásá only contradicting the "rule" that syllables containing the high vowel /i/ are performed on the ojú ojo membrane, and the syllable o was performed as a mute stroke on the ojú òjò, thus dropping the sásá stroke that would be otherwise required when rendering a syllable on an non-high vowel /o/.

\section{Contrast and compensation}

In some cases, drummers may choose not to articulate (by not playing a stroke on) one or a few syllables. This happens mostly due to sound similarity (either by vowel, in CVV sequences, or by pitch) to the preceding syllable(s), a procedure common also in spoken Yoruba (Orie and Pulleyblank, 2002). After an omitted syllable, a high-pitched syllable is likely to be represented by a sásá stroke only, regardless of its vowel. The function of this transformation could be understood as a compensation of the preceding omission, as rendering a high-pitched syllable on sásá only would enhance its contrast to the surrounding syllables. Since a single sásá stroke is always understood as a mi, regardless of vowel, using this stroke after an omitted syllable could be regarded as a way of reinforcing the pitch of the subsequently played syllable.

A glance on a iyáàlù bàtá spectrogram (Figure 6) reveals that its speech surrogacy is based solely on combinations of the sounds shown above:

The sustained low fundamental frequency of the open tone can be recognized on the spectrogram above as a horizontal line at the bottom of the sound spectrum (e.g., syllable Bàbá, at the beginning of the sentence). The mute tone appears in the shape of a white vertical line and slightly higher on the spectrum, indicating an intense sound of short duration and covering a rather wide range of medium-low frequencies (e.g., the three syllables àga pupa in the end of the phrase). The slap can be identified on the spectrogram as a thin vertical line of low intensity and short duration, covering a range of medium-high frequencies (e.g., syllable Bàbá, at the second position). The sásá strokes appear on the top of the spectrum and can be visually distinguished from the ojú òjò strokes as a range of intense high frequencies. From all syllables on this sentence, only lórí and pupa are rendered without the addition of the sásá stroke, following the rule 


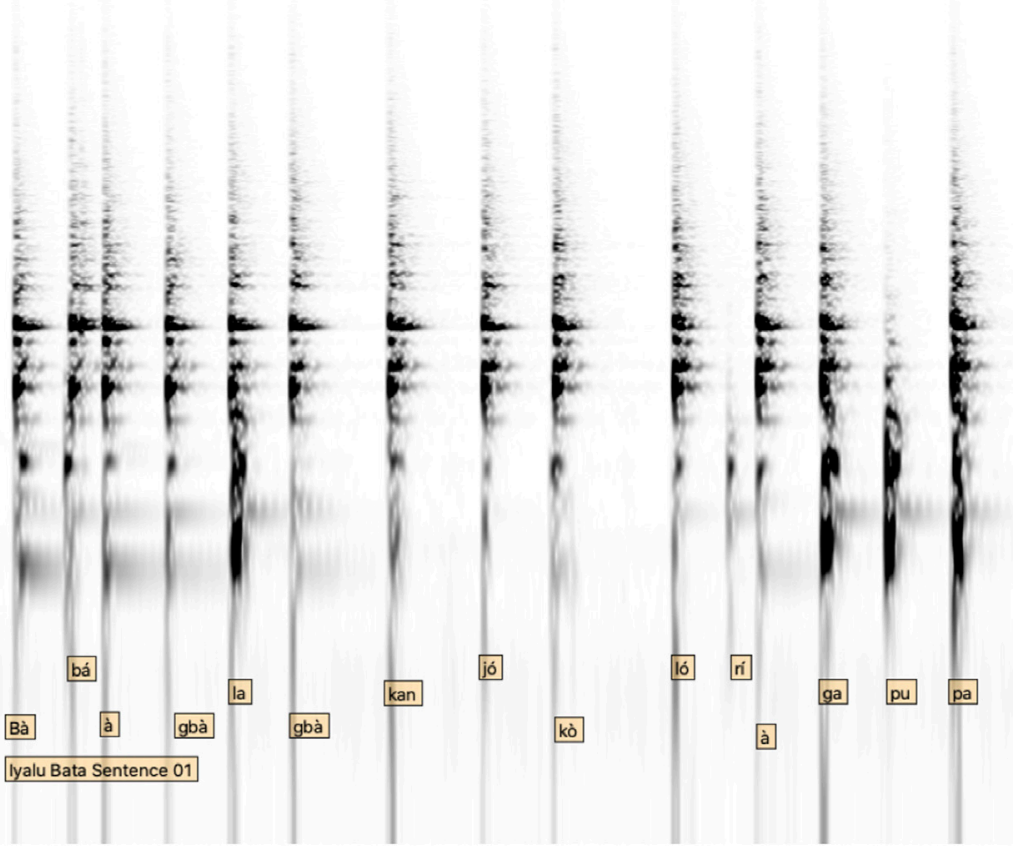

FIGURE 6 | lyáàlù bàtá spectrogram for the sentence "Bàbá àgbàlagbà kaán jókòó lórí àga pupa" ("there is an old man sitting on a red chair").

described on the table above regarding the representation of syllables containing the vowels $/ \mathrm{i} /$ and $/ \mathrm{u} /$.

\section{The Phonology of the lyyáàlù Bàtá}

Of the set of 12 sentences (version 1, in speech mode) performed on the iyáàlù bàtá for the present study, 51 of the 55 occurrences of the vowels /i/ and / $\mathrm{u} /$ (including the tonal variations /í/, /i/, /ú/ and $/ \grave{\mathrm{u}} /)$ ) were performed according to the rules stated above, proving this to be a consistent trait of the iyáallu bàtá speech surrogacy. However, the fact that the iyáálù bàtá does not render the language tones through pitch distinctions (as it is the case on the dùndún speech surrogacy), but rather also through contrasting sound spectra emerging from the different hand playing techniques, leads to further questions regarding the nature of the mapping between drum and language sounds seen here.

Different from the low, mid and high pitches and their contours as performed on the dìndun drum, which consist of different frequency modulations of the same basic timbre, much like the different keys of a piano, or different notes on a violin, the basic sounds of the iyáàlù bàtá are mapped to the Yoruba tones based on their timbre. Timbre is acoustically described as a combination of factors including attack and decay rates, overtone structures (the sound spectrum), and wave shapes. As such, it is not per se a matter of pitch, but of sound quality, and thus phonetically closer to the characterization of vowel sounds than to aspects of linguistic tone. Thus, the different degrees to which the spectra of the open tone, the mute tone and the slap of the ojú ojo contain the fundamental frequency of the vibrating membrane (present virtually only in the open tone), and its overtones (present in increasing degree on the mute tone and slap), correspond acoustically to the overtone spectra responsible for the distinction between vowels in ordinary speech under the influence of formants. The question arising from this observation is why and how pitch and timbre seem to appear here as exchangeable representations of speech tone on the drums.

One important hint can be extracted from the emic perspective represented by our main bàtá informant, a master drummer from the Ayan tradition, who opted to remain anonymous. He states that the general practice is to play the sásá simultaneously with the ojú ojò anytime a word with ohùn ò $\dot{e}$ (high pitch "mi") is to be rendered, and that it is only on rare occasions that a high-pitched syllable is performed only the ojú ojò (personal communication on February 5, 2020). According to him, this tends to happen during fast performance, as a facilitating technique in quick rhythms. Thus, the connection between drum strokes and vowel qualities that our dataset shows is explained as a practical matter of performance speed.

This same apparent contradiction is visible in Villepastour's argumentation (2010, p. 51), whose main informant also conceptualizes the playing of the ojú ojò slap sound without the sásá on high-pitched syllables as a matter of performance tempo. Villepastour, in trying to understand the vowel height representation on the iyáàlù bàtá, refers to Hughes (2000) observations on the usage of the so-called "nonsense-syllables" in mnemonics of diverse musical styles across the globe, defending some universals in the way (instrumental) musical sounds are vocalized, whereby low sounds, e.g., large drums or deep string registers, tend to be imitated by syllables containing 
the vowels $/ \mathrm{i} /$ and $/ \mathrm{u} /$. Her justification for this mapping, is that "while these (the $/ \mathrm{i} /$ and $/ \mathrm{u} /$ ) vowels take less time for a human to utter, they also take less time for an alubàtá to play, as he only uses the strong hand to do so" (Villepastour, 2010, p. 51). This justification, while still lacking on quantifiable evidence, appears to be in line with a specific native perspective on the bàtá speech surrogacy, which links the dropping of the sásá strokes in some cases to concerns of performance tempo.

Yet, whereas time, according to the arguments above, seems to be the central factor from the perspective of the physical processes of sound production, an aural-acoustic approach offers an alternative justification to the mapping between high-vowels and the absent sásá stroke evident in the data. Oyelami states that "what they [the strokes on the ojú òjò only (without sásá) and the high vowels] have in common is the fact that the /i/ and /u/ are similar when you think of softness ... when you don't have the bílálà together with it" (personal communication to Villepastour, 2010, p. 49), arguing in favor of a mapping based on sound perception and aural sensibility, rather than one based on physical constrains of sound production.

It is relevant to ponder on what Oyelami could be in fact alluding to, when referring to the "softness" of the vowels /i/ and $/ \mathrm{u} /$. Besides being considered vowels of low intrinsic intensity - a relevant factor for the iyáàlù dùndún speech surrogacy, as described above - the closed vowels /i/ and / $\mathrm{u} /$ also share a similar organization of their harmonics, or overtones, which differs from the spectra of open or non-high vowels. The image below (Figure 7) shows the contrast between the high vowels $/ \mathrm{i} /, \mathrm{u} / \mathrm{and}$ the non-high /a/ vowel as pronounced by a Yoruba native speaker. It is noticeable that the overtone structure of the /a/ vowel occupies a much higher frequency range, while the spectra of the /i/ and /u/ vowels are more compact. Besides, both the $/ \mathrm{i} /$ and $/ \mathrm{u} /$ spectra concentrate more energy on the first and third overtones, which vibrate in a $2 / 1$ and $4 / 1$ harmonic ratio to the fundamental, respectively, and are perceived as a consonance or even as the same sound (unisono). The spectrum of the /a/ vowel, instead, activates a higher number of frequencies of diverse, more dissonant proportions. Both these characteristics of high vowels-the more compact spectrum, and the concentration of energy in more consonant overtones - contribute to a perceived "softness," when compared to the diffuse spectrum of non-high vowels, which can be perceived as harsh or shrill.

Similarly, the spectral analysis of iyáàlù bàtá strokes (Figure 8) shows that, while ojú òjò strokes - as used to render the $/ \mathrm{i} /$ and $/ \mathrm{u} /$ vowels - display a rather low and compact overtone spectrum, the sásá, commonly added to the ojú òjò when performing all further (non-high) vowels, displays a high and more diffuse spectrum.

While addressing this question, additionally, it has to be kept in mind that the iyáàlù bàtá is a two-headed conical drum (in the Sachs-Hornbostel systematics of musical instruments: 211.252.818, Sachs et al., 1986, pp. 174-181), whereby each membrane is at one end of the same (closed) air column. This means that every vibration caused on one membrane will naturally resonate on the opposite membrane, interfering with its own vibration and causing the sound spectra of both

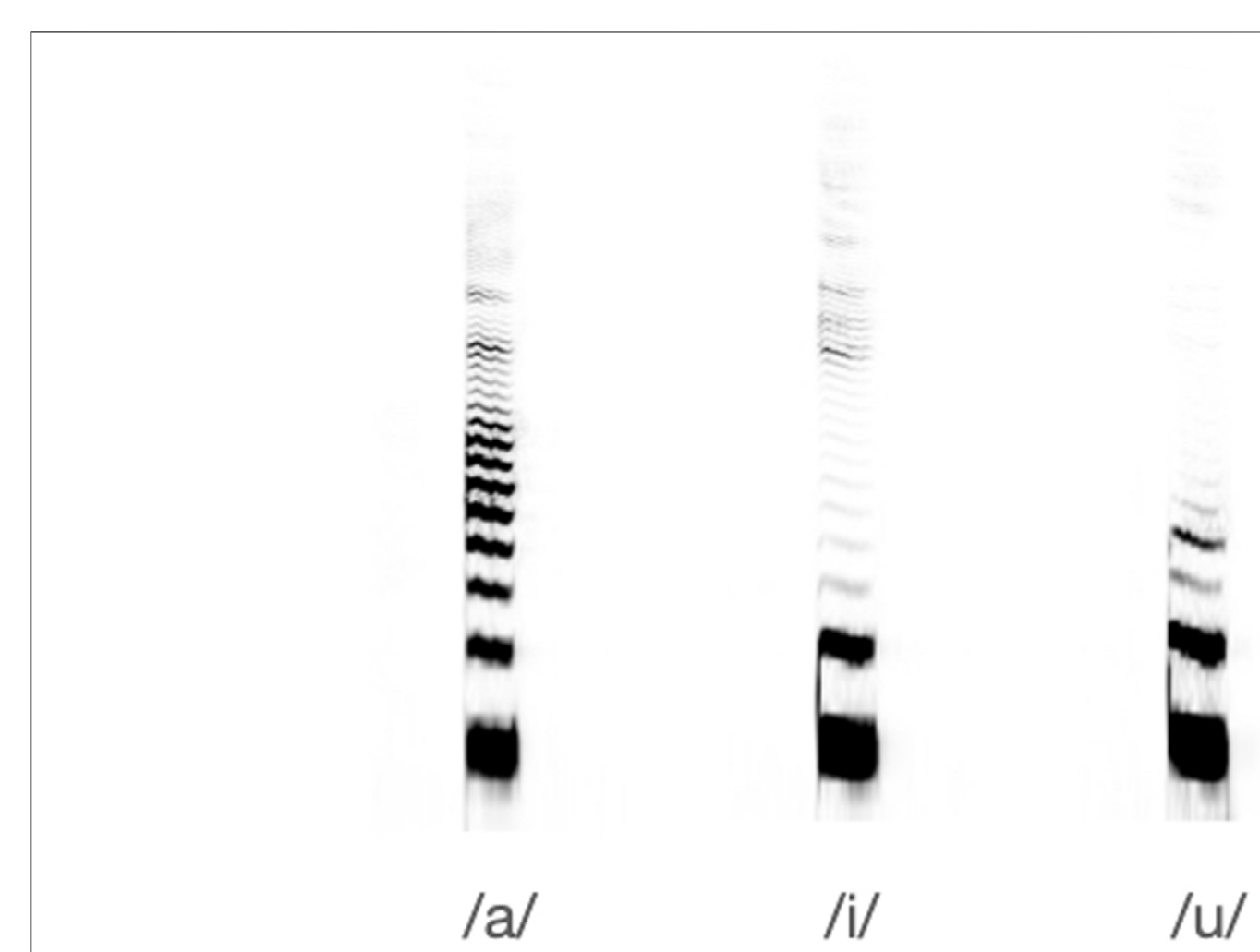

FIGURE 7 | Spectra of the vowels /i/, / $/$ / and /a/ as pronounced by a Yoruba native speaker. 


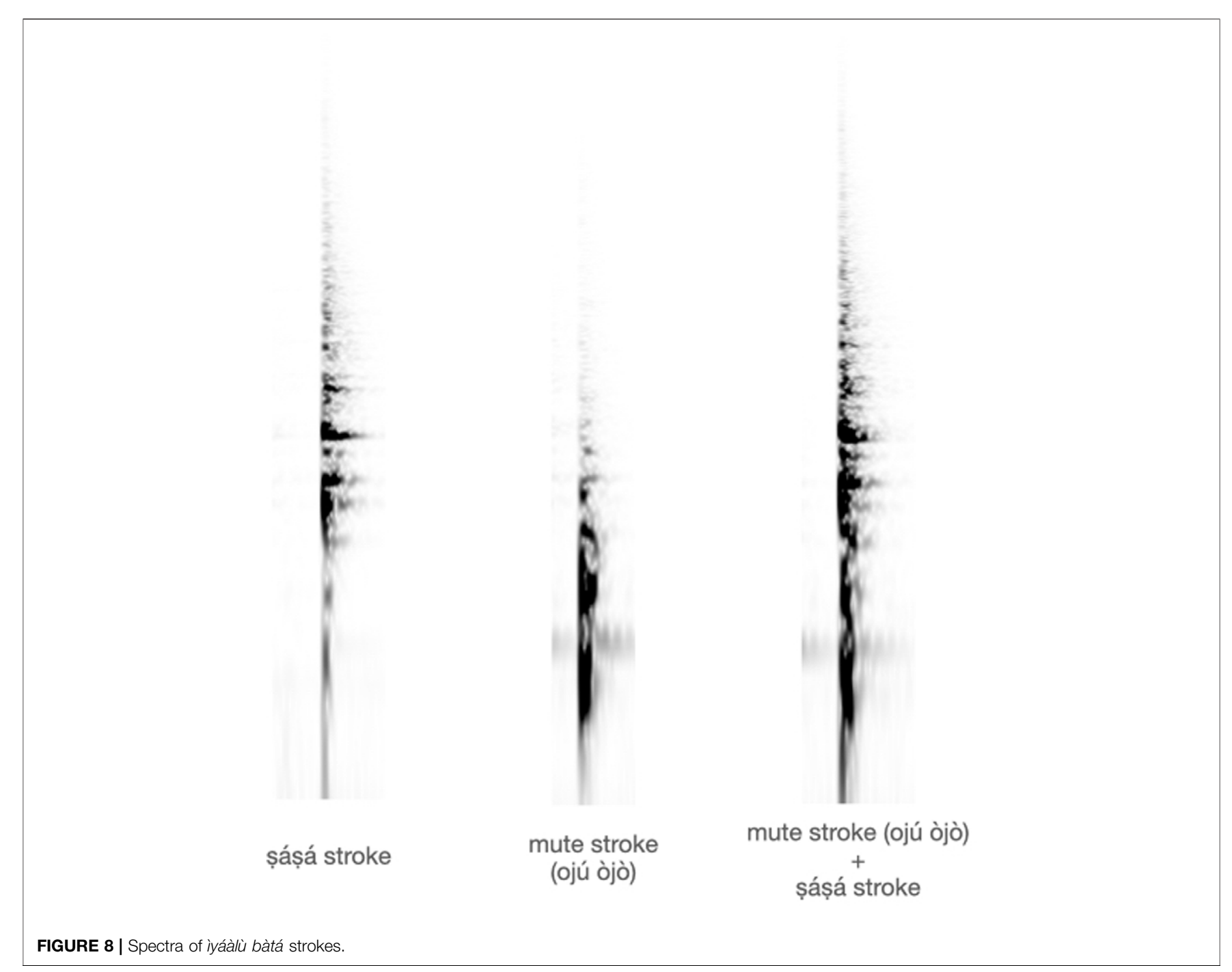

drumheads to merge. This is noticeable on the spectrogram images of the different iyáàlù bàtá stroke combinations, showing that the frequency spectra of the sásá and the ojú òjò membrane do overlap each other partially on the mid region. Thus, more than simply combined, the two independent membrane sounds can be said to be acoustically intertwined.

The consideration of the spectral characteristics of the /i/ and $/ \mathrm{u} /$ vowels in relation to this particular organological feature of the iyáàlù bàtá reveals that, while the imitation of the low, mid and high speech tones on this drum is achieved by means of low, mid and high spectra, respectively, its vowel representation maps vowel spectra to actual drum sound spectra, imitating them through their own acoustic means. This observation is crucial in questioning Villepastour's classification of the dùndún and the bàtá drums as standing on opposite sides of a continuum between "mimicking" and "encoding," whereby the bàtá would rather "encode" than "mimic" language (2010, p. 90). Understanding the iyáàlù bàtá as an "encoder" obscures the factual sound similarities between language and drum sounds which underlie its speech surrogacy system.
Yet, in spite of the sound similarities mentioned above, the bàtá drum language is considered, even among Yoruba cultural insiders, as difficult to understand, especially when compared to the dùndún. The bàtá, then, is often referred to as an akólòlò, a polysemous Yoruba term (Bello 2020), whose interpretation and most adequate English translation itself have become subject of discussion among scholars. Villepastour devotes a great deal of attention to this term, refuting the translation of akólòlò by Láoyè-himself a drummer, music researcher and Yoruba king-as "stammerer" (Láoyè 1959 cited by Villepastour, 2010, p. 122) and suggesting an interpretation as "the one who speaks in a staccato manner" (Villepastour, 2010, p. 122), shifting the focus to the acoustic impression of the bàtá drum language, which consists indeed of sequences of short sounds, in contrast to the sound continuum promoted by the long sustain time of the dùndún.

However, the term kólòlò means more than "stammer" or "stutter." It is also used, for instance, for someone who, in spite of having no speech impediment as such, is not articulate or confident in speech, and especially someone not fluent in 
communicating in Yoruba Language. In other words, just as a person who stammers due to a speech impediment is referred to as "akólòlò," so also is a person (native or non-native speaker) called "akólòlò," if they cannot express themselves clearly enough in Yoruba Language for another native speaker of the language to comprehend the message or communication easily and fully. Yoruba scholars such as Euba (2011), Omojola (2012), and Olatunji (2012), discussing the reason why the batá is called akólòlo in Yoruba culture, support that the word akólòlò does not imply that the bàtá has a speech impediment, but that a single bàtá drum cannot independently communicate in Yoruba. This is because, in the traditional performance setting of a bàtá ensemble, the iyáàlu bàtá is supported by the omele abo bàtá, whose player "doubles" the iyáàlù's mute strokes with its own representation of the mid speech tone, enhancing the intelligibility of the message. Evidently, this combination of two drums played by two drummers to render one same sentence can only be achieved within performances of previously known texts, which is different from the experimental approach pursued by the present study but represents the majority of the conventional practice of a bàtá ensemble. The semantic pluralism in the use of akólòlò in Yoruba culture can be better understood by one of many rich Yoruba proverbs-“b’ópé b’óyá, akólòlò á pe bàbá" ("eventually, a stammerer will say the word father"). One of the proverb's interpretation is that a stammer can and will eventually communicate his/her message, if given time, space, and opportunity. In this context, the bàtá drum can and will talk if given the time (it is longer and more difficult to comprehend the bàtá drum text than the dùndún), space (the iyáàlù bàtá engaging different timbre on the ojú òjò and sásá strokes for its speech surrogacy), and opportunity (the iyáálù and omele abo bàtá combining for complete communication of sentences). According to this interpretation, bàtá drums are referred to as "kólòlò" (stammers) not because they cannot "mimic" the Yoruba Language, but because it is more difficult for a single bàtá to communicate efficiently than it is for a single dùndún drum. This is also one of the reasons why in Yoruba culture, the dundún is more popular for musical arts and speech communication than the bàtá.

\section{The Bàtá Players' Perspective on Yoruba Speech Tones}

Yoruba speakers refer to the three speech tones as ohùn isàle ("low/down voice"), ohùn àárín "mid voice"), and ohùn òkè ("high/upper voice"). However, in addition to these native terms, Yoruba drummers also view and relate to these words in a native acoustic concept, that is, the way it appears and sounds to them from their drumming practice. For example, due to the deep reverberations of the ohùn isàlè on the drums, they often refer to such tones as "ohùn kèkè." The kèkè is an onomatopoeic word representing the bass acoustic reverberation, gotten from the repetition of the Yoruba word " $k e$ " (deep, bass sound) with a low pitch. The ohùn àarin is referred to as kele, two words with the same (mid pitch) tone sound, with the "le" being an onomatopoeic word representing a similar or repeated soft acoustic sound. The drummers refer to ohùn òkè as either kúrún or aago (or agogo). In the Yoruba language, just as a high pitch sound is perceived as kúrún (with two high pitch syllables), any acoustic sound with high pitch is also said to "ró bii aago" (ring like a gong/bell). Similarly, a person (or instrument) with a high-pitched voice is said to have a voice like a gong/bell (al'óhùn bii aago). Hence, both linguistically and acoustically, the Yoruba people (speakers and drummers) conceive speech intonation in their language and (drum) music both in space (ohùn isàlè, àárín, and òkè) and sound (ohùn kèkè, kele, and kúrún or aago).

\section{The Secret Language Ená Bàtá}

Ȩnà bàtá is a secret language used by bàtá players and plays a major role in Villepastour's monograph on bàtá speech surrogacy. Villepastour presents ęnà bàtá as a "formal language" that acts as an "interface" (p. 107) between spoken Yoruba and the "machine language" (idem) represented by the bàtá drum speech rendering. This view, however, is contested by Euba (2011, p. 518), who considers the ená bàtá to be of lesser importance for the speech surrogacy on bàtá drums.

Villepastour's account of the ená bàtá does not constitute a proof of the necessity of this artificial language for the praxis of bàtá speech surrogacy. On the contrary, the linguistic information contained in sentences played on a iyáàlù bàtá can be regarded as even closer to its spoken equivalent in Yoruba language, than its ená bàtá version. Although Villepastour's main informant, Ayandokun, seems to employ ęnà bàtá systematically as an important step in the translation from a spoken into a drummed phrase, Villepastour does not extensively argue for the need she sees "for an interface (that is, an intermediate language) between the natural language of Yorùbá and the machine language of the bàtá" (Villepastour, 2010, p. 108). As a form of "oral notation" (Kubik, 2010), it is clear that ená bàtá, when used for this purpose, can facilitate the memorizing and teaching of a specific drum pattern. However, it cannot be regarded as a linguistically necessary step for the production the bàtá drum language as such, but as an - undoubtedly interesting and culturally important-related subject.

Instead of a crucial interface between spoken Yoruba and the bàtá drum language, as postulated by Villepastour, we propose that ená bàtá could be better understood as a helpful method for teaching and memorizing and as a specific form of code talking (Isola, 1982), which is a common practice among the Yoruba. In this sense, in ená bàtá, bàtá drummers may be taking advantage of one aspect of their art when transforming the Yoruba language to create their own form of code talking.

\section{THE OMELE BÀTÁ SPEECH SURROGACY}

The omele bàtá consists of three small sized drums (ca. $20 \mathrm{~cm}$ height) that are bound together and hung with a strap on the drummer's shoulder. The construction of the three drums is identical and resembles a miniature version of the larger bimembranophones of the bàtá family, such as the iyáàlù bàtá discussed in this study, featuring the same drum shape, type of 
drumhead and rim, as well as a similar attachment system with animal skin. In spite of having two membranes, the drums are carried vertically in front of the player, whereby only the upfacing larger membranes are played. The membranes are hit with two flexible strips of dried animal skin called bilálà, identical to the one used to hit the sásá (small membrane) of the iyáàlù bàtá.

Unlike the dùndún drums discussed above, the tuning of the drums of the bàtá family is fixed, and no changes of tuning can be undertaken by the player on the go. However, a tuning paste called ida, made from tree resin and charcoal, is applied to the center of two of the larger membranes of two of the drums, lowering their pitches. Normally, drummers will check the tuning before playing, and adjust the position, shape and, if necessary, also the quantity of $i d a$ applied to each drum, in order to get the desired sound.

\section{Basic Rules}

The speech surrogacy of the omele bàtá can be said to unite some of the advantages of both the dùndún and the iyáàlù bàtá drums. With three different membranes tuned to three contrasting pitches, the omele bàtá is able to represent the three tones of the Yoruba language by means of pitch differences. In this aspect, omele bàtá sounds can be considered acoustically closer to spoken Yoruba than the speech surrogacy of the iyáàlù bàtá, which represents tone by means of contrasting sound spectra. Moreover, the possibility of striking two membranes simultaneously with the 2 bilálà allows the drummer to partially apply the i-and-u-rule described above for the iyáàlù bàtá. However, these rules are applied less consistently on the omele bàtá than on the iyáálù bàtá.

Different from the iyáàlù bàtá, the omele bàtá is also used to render the $/ \mathrm{r} /$ consonant by means of rapid flam strokes (rapid sequence of two strokes on the same membrane, one hand after the other). Although this trait is observed in our dataset only on the high-pitched membrane (mi), our informants support that it can occur in the mid and low membranes as well.

General regularities of the omele bàtá speech surrogacy:

1. The three drums (omele ako, kúdi, and àdàmò) are assigned to the three Yoruba speech tones (ohùn isàlè, àárín, and òkè), representing the $\mathrm{L}, \mathrm{M}$, and $\mathrm{H}$ speech tones (do, re and $\mathrm{mi}$ ) (1a, $2 \mathrm{a}$ and $3 \mathrm{a}$ on Figure 9).

2. When two of the drums are played simultaneously (double lines), the combinations $\mathrm{H}-\mathrm{L}$ and $\mathrm{H}-\mathrm{M}$ render the speech tones do and re, respectively, in non-high vowels.

3. For the speech tones do and re, when rendering syllables containing the soft vowels /i/ and / $\mathrm{u} /$, the representations in rule 1 are preferred.

4. Syllables on high speech tone containing intense vowels are mostly rendered as a double stroke on the high-pitched membrane (3b)

5. The double mi stroke (3b) can also be played sequentially in a quick rhythm, rendering the $/ \mathrm{r} /$ consonant in a high-pitched syllable.

When considering the rules above, it is noticeable that the omele bàtá, as a more recently created instrument, displays a speech surrogacy system easily relatable to the playing patterns of the iyáàlù bàtá, which relies largely on the parallel playing of two membranes to render vowel height. On the omele, the highpitched membrane, just like the sásá on the iyáàlù, serves a double function, acting both as a representation of the high speech tone, and as a vowel quality marker on non-high vowels. However, three fundamental differences between the two drums should be highlighted here. Firstly, the omele bàtá, with three independent membranes, is able to render speech tone through actual pitch distinctions, i.e., through distinct fundamental frequencies. On the iyáàlù bàtá, as mentioned before, this differentiation is largely based on timbre-i.e., sound spectra. Secondly, the omele consists of three independently constructed drums, which are not attached to each other but through the carrying strap. Thus, they are also acoustically largely independent from each other, causing their sounds, when played simultaneously, not to merge with each other in the same way the ojú òjò and sásá sounds of the iyáàlù bàtá do. Thirdly, on the omele bàtá, the three membranes have similar sounds, varying virtually only in the pitch they are tuned to. Therefore, when played simultaneously, they tend to sound like an interval (i.e., the simultaneous playing of two pitches or "notes" in the conventional sense of Western music theory), instead as two complementary timbres, as it is the case on the iyáàlù bàtá.

Villepastour (2010, p. 89) argues that as a speech surrogate, the omele bàtá is advantageous over the iyáàlù bàtá. Her reasoning is based mostly on the fact that the omele bàtá renders speech tones by means of actual pitch distinctions, which leads, arguably, to more clearly distinguishable representations of speech tone. On this instrument, additionally, it is possible to render the $/ \mathrm{r} /$ consonant. However, the differences listed above indicate that the omele bàtá is not fully capable of imitating vowel spectra, as seen on the iyáàlù bàtá. The high pitched sásá of the iyáàlù bàtá appears to complement the high frequency spectrum on intense vowels, which is not fully applicable for the omele bàtá. On the omele bàtá, unlike the iyáàlù bàtá, single sounds of individual membranes do not merge, but are rather perceived as intervals, which is distant from the original aurally rooted system of vowel imitation of the iyáàlù bàtá. This means that the vowel rendering technique of the omele bàtá could be understood as a formal device borrowed from the iyáàlù bàtá technique, employing similar sound connections, yet without its underlying aural groundwork. It may be concluded that the omele bàtá is used to (partially) implement phonological distinctions originating from an aural effect that is not present on this instrument.

\section{EXAMPLE OF FULL SENTENCE ANALYSIS}

Our main aim in this study was to provide adequate data for comparing the speech surrogacy of the most popular Yoruba "talking" drums. Our dataset is made up of renditions of 12 different sentences on the gángan, iyáàlù dùndún, iyáàlù bàtá and omele bàtá. In this section we illustrate these renditions for the sentence "Bàbá àgbàlagbà kaán jókòo lórí àga pupa" ("Father - old - a certain sits on - chair - red" or "there is an old man sitting on a red chair"). 


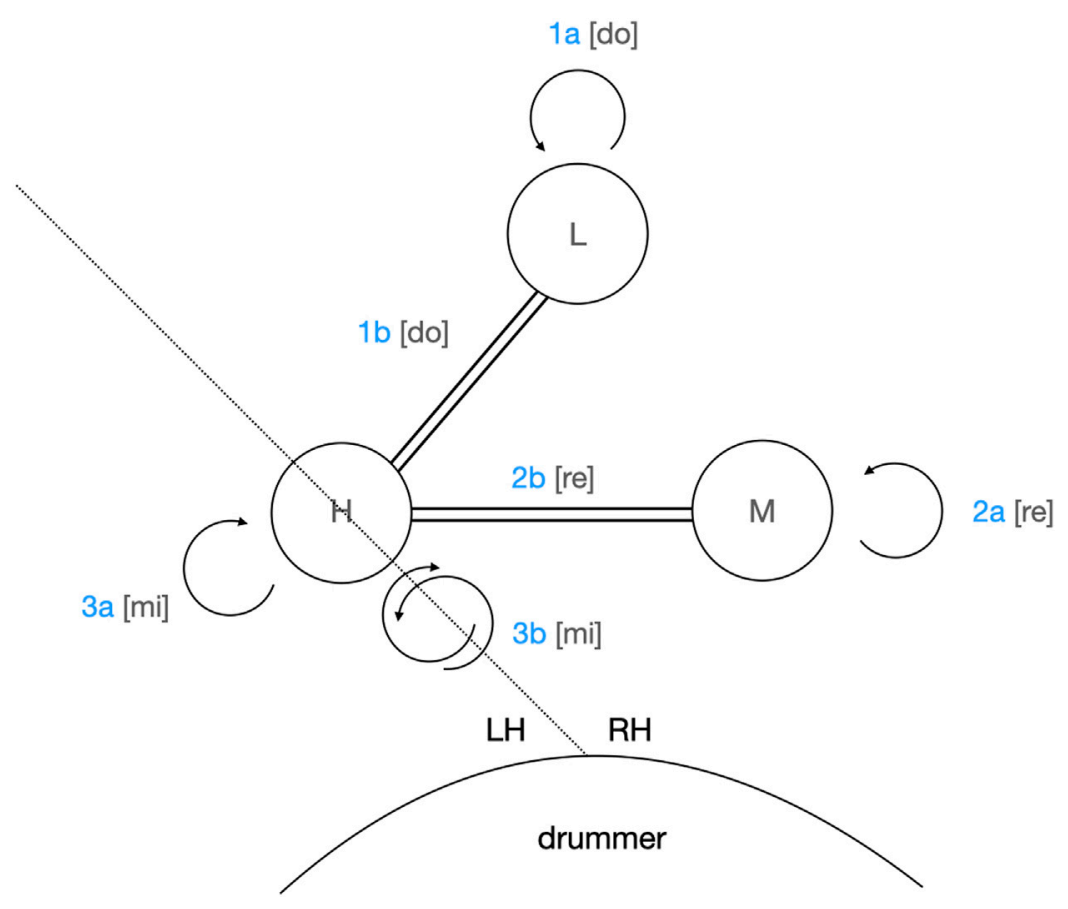

FIGURE 9 | Graphic representation of the omele bàtá speech surrogacy system.

In this sentence, both recordings of dùndún drums display a similar overall melodic pattern with a clear correspondence between speech syllables and drum strokes. However, some differences between the patterns played demonstrate how dùndún players can choose between the representation of distinct phonological features in rendering one drummed phrase and how the distinct sizes of the iyáalù dùndún and the gángan affect their acoustic possibilities when mimicking Yoruba speech (Table 2).

The words "Bàbá àgbàlagbà kaán" are rendered in the same way in both dùndún samples:

- "Bàbá" is represented with an upwards gliding pitch in both versions [do][ $\wedge$ mi].

- Both drummers represented the vowel sequence "Bàbá àgbà" by slowly dropping the tuning tension without a new onset before the next syllable, thus creating a ligature between the high pitch $[\wedge \mathrm{mi}]$ and the following pitch $(\vee \mathrm{do})$.

- Both drummers represented the word "kaán" ("a certain") with an upwards gliding pitch. The gángan version includes a prolonged pause after this syllable.

- Both versions differ on the representation of "jókòó". The iyáàlù dùndún version features a slow upwards glide $[\mathrm{do}](\wedge \mathrm{mi})$, whereas the gángan version seems not to represent the last rising contour of the word but with an extended pause after the low [do].

- The iyáàlù dùndún version represents the /r/ in "lórí àga" by performing the pitches [mi][do] on a fast bouncing (double) stroke. This representation is left out on the gángan version. - On the iyáàlù dùndún version, the /u/ vowel in "pupa" is rendered with a softer sound than the surrounding words. On the gángan version, no such intensity contrast is found.
Both bàtá drums, as played by the same drummer, largely rely on the basic rules of syllable-tone-pitch correspondence and the i-u-rule as described above. The few exceptions are interesting and reveal some phonologically relevant features of the bàtá speech surrogacy. Notably, two very distinct applications of rhythmically shorter strokes, or "flams", can be observed in the iyáálù bàtá versions (Table 3).

- On the iyáálù bàtá, all syllables were performed according to the i-u-rule described, with the exception of the strokes involved in glides (see below). On the omele bàtá, the rule is applied to only one third of the strokes. The basic correspondence between syllable speech tone and played stroke is observed throughout both recordings.

- The iyáàlù bàtá version renders the vowel sequence "Bàbá àgbà" with a flam from the sásá [mi] and ojú òjò slap [mi] to the ojú ojjò [do] (open tone). Seemingly, the short rhythmic figure is used here to represent the vowel sequence.

- Both versions feature a longer pause after "kaán". This could be a way of representing the rising intonation of this word, as seen on both the dùndún and spoken versions of the sentence, as well as the prolonged duration of this word due to the nasal $/ \mathrm{n} /$. - Both versions use quick rhythms in the representation of the /r/ in "lórí àga". In the iyáàlù version, due to the presence of the /i/ vowel, this is achieved through a quick movement from the slap to the open tone (ojú ojò), a technically demanding stroke sequence at this speed.

- Both versions render the syllable "jókòó" on a single stroke, in a similar fashion to the gángan version, whereby the last high pitch contour is not displayed with a sound (e.g., a flam), but rather with the insertion of a pause after the low pitch. 
TABLE 2 | Transcriptions of the sentence "Bàbá àgbàlagbà kaán jókòó lórí àga pupa" ("there is an old man sitting on a red chair") on the dùndún drums. (A) lyáàlú dùndún. (B) Gángan.

(A) İyáàlú dùndún
\begin{tabular}{|l|l|l|l|l|l|l|l|l|l|l|l|l|l|l|l|l|}
\hline do & $\wedge$ mi & $(\vee$ do $)$ & do & re & do & re $\Lambda$ & $\mathrm{mi}$ & do & $(\Lambda$ mi & mi & & mi & do & re & re & re \\
\hline Bà & bá & $\grave{a}$ & gbà & la & gbà & kaán & jó & kò & ó & ló & & rí & à & ga & pu & pa \\
\hline+ & + & + & + & + & + & + & + & + & + & + & & + & + & + & - & + \\
\hline
\end{tabular}

\section{(B) Gángan}

\begin{tabular}{|l|l|l|l|l|l|l|l|l|l|l|l|l|l|l|l|l|}
\hline do & $\wedge$ mi & $(\vee$ do & do & re & do & re $\Lambda$ & & mi & do & & $\wedge$ mi & mi & do & re & re & re \\
\hline Bà & bá & à & gbà & la & gbà & kaán & & jó & kò & & ló & rí & à & ga & pu & pa \\
\hline
\end{tabular}

TABLE 3 | Transcriptions of the sentence "Bàbá àgbàlagbà kaán jókòó lóríàga pupa" ("there is an old man sitting on a red chair") on the bàtá drums. (A) Omele bàtá. (B) liyáálù bàtá.

(A) Omele bàtá
\begin{tabular}{|l|l|l|l|l|l|l|l|l|l|l|l|l|l|l|l|l|l|l}
\hline Left Hand & mi & mi & mi & mi & mi & mi & mi & & mi & & & mi & & mi & & & & mi \\
\hline Right Hand & do & mi & do & do & re & do & re & & mi & do & & mi & & mi & do & re & re & re \\
\hline & bà & bá & à & gbà & lag & bà & kaán & & jó & kòó & & ló & & rí & à & ga & pu & pa \\
\hline
\end{tabular}

(B) İyáàlù bàtá

\begin{tabular}{|l|l|l|l|l|l|l|l|l|l|l|l|l|l|l|l|l|l|l|l|}
\hline Sásá & $\mathrm{mi}$ & $\mathrm{mi}$ & $\mathrm{mi}$ & $\mathrm{mi}$ & $\mathrm{mi}$ & $\mathrm{mi}$ & & $\mathrm{mi}$ & & $\mathrm{mi}$ & & & $\mathrm{mi}$ & & & $\mathrm{mi}$ & $\mathrm{mi}$ & & $\mathrm{mi}$ \\
\hline Ojù̀ òjò & $\mathrm{do}$ & $\mathrm{mi}$ & $\mathrm{do}$ & $\mathrm{do}$ & $\mathrm{re}$ & $\mathrm{do}$ & & $\mathrm{re}$ & & & do & & $\mathrm{mi}$ & & $\mathrm{mi}$ & $\mathrm{do}$ & $\mathrm{re}$ & $\mathrm{re}$ & $\mathrm{re}$ \\
\hline & bà & bá & àg & bà & lag & bà & & kaán & & jó & kòó & & ló & & rí & à & ga & $\mathrm{pu}$ & $\mathrm{pa}$ \\
\hline
\end{tabular}

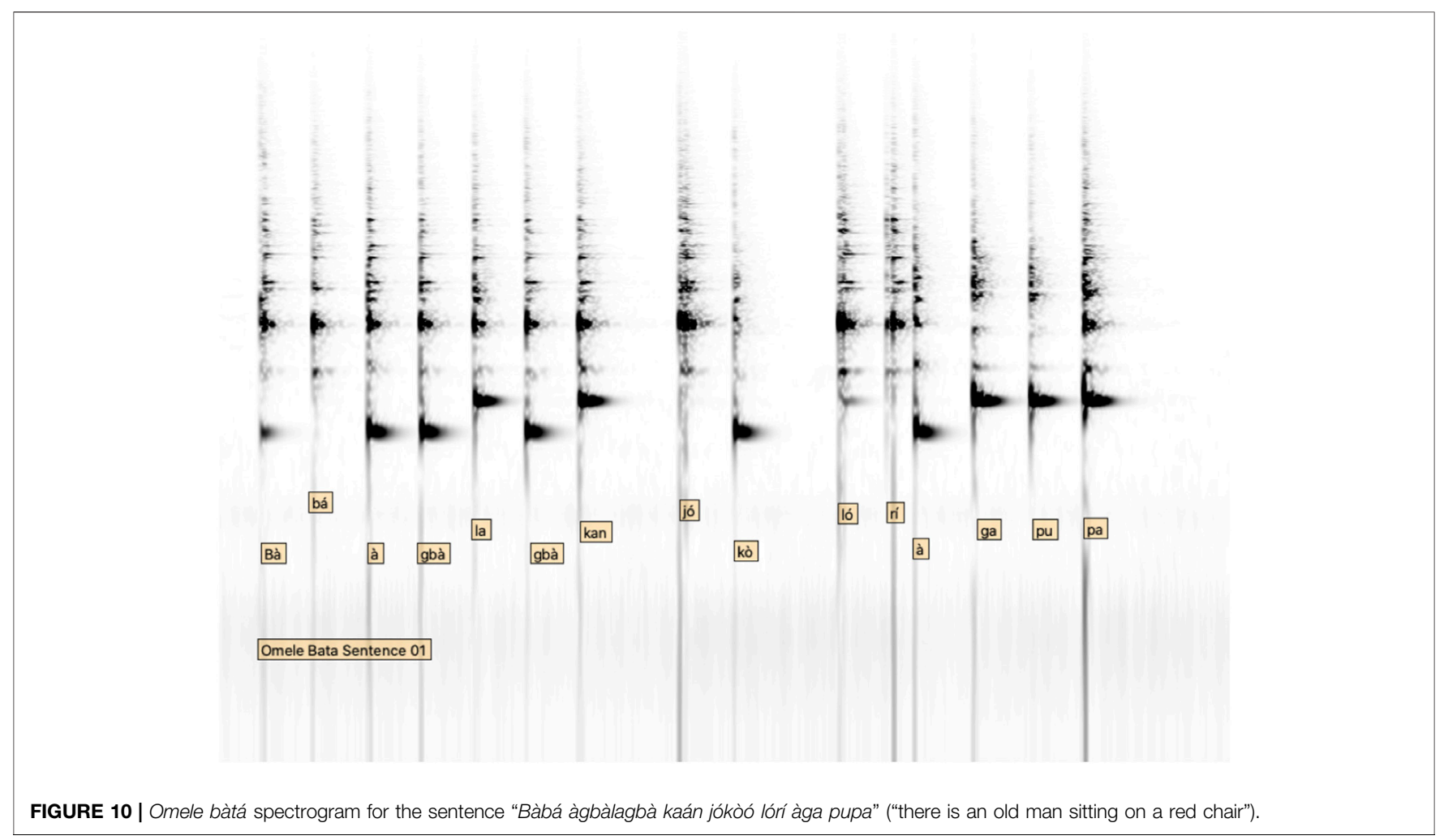


- The spectrogram of the omele bàtá version (Figure 10) shows a great rhythmic regularity (average IOI-Inter Onset Intervals), with clearly longer IOI after "kaán" (re with rising pitch) and "kòo" (vowel sequence with upwards glide on the same vowel), and a shorter time interval rendering the $/ \mathrm{r} /$ consonant. Apart from these exceptions, all IOI are virtually equal.

- Similarly, the rhythm used in the iyáàlù bàtá (see Figure 6) version is constant, being interrupted by the flams and prolonged pauses mentioned above. One additional pause can be seen after "àgbàlagbà" for a reason that is yet unclear.

The analysis of this sentence, as recorded by three drummers ad hoc, without knowing the sentences in advance or having substantial time for preparation, shows that the regularities described above largely apply on their drum performances. On the dundún drums, both drummers respected the basic tone contours of Yoruba. As expected, both versions differ in their use of glides and of the double stroke on the imitation of the $/ \mathrm{r} /$ consonant. Furthermore, the gángan version does not differentiate between vowel intensities. Similarly, the bàtá versions largely obey to the regularities demonstrated above, with the omele bàtá versions proving to apply the vowel related rules less regularly.

\section{FINAL CONSIDERATIONS}

The dùndún and bàtá drums that were discussed in this paper differ in their organological features and sound production. Accordingly, in spite of being both used as speech surrogates, they differ in their means of doing so. The dùndún drums have a flexible tuning system and can be used to quite accurately depict the tonal inflections of spoken Yoruba. The iyáàlù bàtá has fixed membranes and therefore cannot perform gliding tones in the same fashion. Nonetheless, the richness of the iyáàlù bàtá timbre enables the differentiation between vowel qualities through the distinct sounds emerging from diverse playing techniques and their combinations. By contrast, the dùndún employs a single playing technique, with the opá producing a uniform timbre over the whole tonal range of the instrument. Accordingly, these drums cannot be used to distinguish between vowels through timbre, and they mark the difference in vowel intensity by means of amplitude. The omele bàtá is only able to produce three different sounds and their combinations, but its speech surrogacy practices represent both tonal aspects of spoken Yoruba and some vowel distinctions. Additionally, each of the three types of drums is able to imitate the sounds of language relating to specific constraints of time, for instance using flams and re-bouncing strokes to resemble the sound of the rolling tongue when of pronouncing an $/ \mathrm{r} /$, or prolonging sounds or pauses to mark, for instance, the length of a nasal coda consonant. In our analysis, we have focused on the organological features and playing techniques of the studied drums, on the way they favor certain phonological elements of the Yoruba language over others. Thus, we propose that drums are not placed along a continuum between "encoding" and "mimicking", as supported by Villepastour (2010, p. 90) but rather between their tendencies to address and modulate each of the intrinsic characteristics of

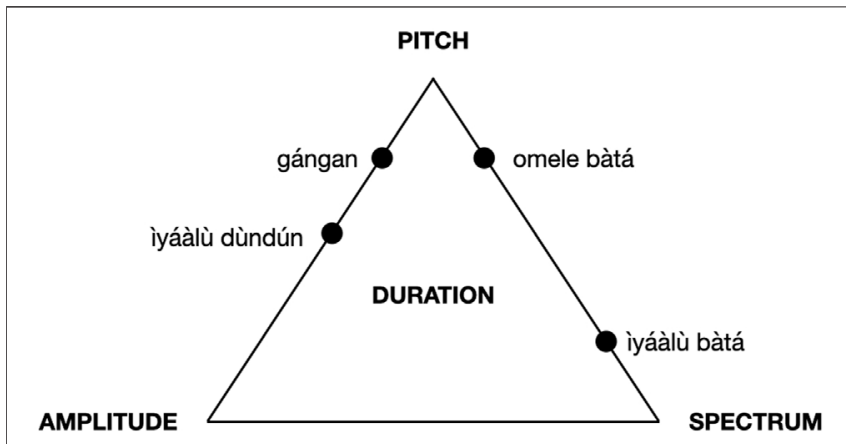

FIGURE 11 | Placement of the studied drums according to their addressing of pitch, amplitude, duration and spectrum.

language sounds: intensity, pitch, duration and spectral composition $^{4}$ when imitating the sounds of spoken Yoruba language (Figure 11).

The iyáàlù dùndún addresses both the tonal inflections of Yoruba and the intensity contrasts between vowels by modulating both pitch and intensity (amplitude) when mimicking them. The gángan, due to its smaller membrane, is less capable of modulating amplitude, but still derives its speech surrogacy from the direct imitation of speech tones and their inflections. The iyáàlù bàtá, although it can hardly mimic the three speech tones, is capable of imitating vowel spectra thanks to a nuanced playing technique and the advantages on a conic drum corpus acting as a closed air column between the two membranes. The omele bàtá, finally, with three membranes tuned to different pitches, is used to imitate the three speech tones of Yoruba language directly. The omele bàtá is also able to mimic to some extent the vowel characterizing system of the iyáálù bàtá, however without relying on a nuanced modulation of sound spectra. Furthermore, it is needless to say that duration-be it in form of musical rhythm, or when imitating the $/ \mathrm{r} /$ consonant - is one element of speech or musical sound necessarily present and modulated in any form of speech or music.

It can be observed that the notions of pitch height, tone spectrum and vowel quality are deeply intertwined in the speech surrogacy systems of the Yoruba "talking" drums. They may be regarded as reflecting an oral culture with high aural sensibility but without the need for a theoretical dissociation of these single acoustic concepts. Furthermore, the great acoustic sensibility in oral cultures (Ong, 1982) offers the possibility to understand drum languages not as surrogates that imitate established (i.e., consciously formalized) language structures, but rather as technologies capable themselves of participating in making these structures tangible. Inasmuch as phonetics and phonology are Western disciplines devoted to the systematization of knowledge around language sounds, drum language systems such as the Yoruba dùndún and bàtá systems are themselves native, concrete strategies of systematization of language sounds

${ }^{4}$ Lexicon of Linguistics, art. "Intrinsic Characteristics" $<$ https://lexicon.hum.uu. $\mathrm{nl} /$ ?lemma $=$ Intrinsic + characteristics\&lemmacode $=1223 \&$ lemma $=$ Intrinsic + characteristics\&lemmacode $=1223>$ (downloaded on 08.01.2021). 
through their transformation and reinterpretation within the acoustic systems made possible by the organological features of musical instruments and their playing techniques. We may therefore view the transformation of sound from speech to drum as a platform of developing a native theory of language, in which the sounds of language are reconsidered inside the framework of an artificial instrument, which helps to represent native introspective aspects of spoken language.

In his early account of the Yoruba drum languages, Ulli Beier seems to find necessary to state that "the talking drum does not use a kind of Morse system, as imagined by most nonAfricans" (Beier, 1954, p. 30), showing that the perhaps most natural assumption made by a (Western) outsider, when first confronted with a seemingly unintelligible practice of speech surrogacy, is that it must contain a specific secret "code" to be revealed. The Yoruba drum languages presented here, however, as we hope to have shown, do not rely on any hermetic coding process, but on the outstandingly cultivated aural sensibility of both drummers and listeners, who are able to navigate and creatively employ diverse relations of sound similarity between the language they speak and the drums they play.

\section{DATA AVAILABILITY STATEMENT}

The transcripts of the audio recordings supporting the conclusion of this article can be made available by the authors upon request.

\section{REFERENCES}

Adegbite, A. (1988). The Drum and its Role in Yoruba Religion. J. Religion Afr. 18 (1), 15-26. doi:10.1163/157006688x00207

Ajiboye, O. (2011). Disambiguating Yoruba Tones: At the Inferface between Syntax, Morphology, Phonology and Phonetics. Lingua 121, 1231-1648. doi:10.1016/j.lingua.2011.05.008

Akinbo, S. (2019). Representation of Yorùbá Tones by a Talking Drum: An Acoustic Analysis. Linguistique et Langues Africaines 5, 11-23.

Arewa, O., and Niyi, A. (1980). Redundancy Principles of Statistical Communications as Applied to Yoruba Talking-Drum. Anthropos 75, 185-202.

Beier, U. (1954). The Talking Drums of the Yoruba. Afr. Music Soc. J. 1, 29-31. doi:10.21504/amj.v1i1.223

Bello, A. M. (2020). "Stylistics of Identity and Ideology in Alter-Native Yoruba Music Textuality. PhD Thesis. Nigeria: Department of Linguistics, African and Asian Studies, University of Lagos.

Euba, Akin. (2011). Review: Villepastour, Amanda. Ethnomusicology 55, 516-520. doi:10.5406/ethnomusicology.55.3.0516

Euba, Akin. (1990). Yoruba Drumming: The Dùndún Tradition. Bayreuth: Bayreuth University.

Hughes, D. W. (2000). No Nonsense: The Logic and Power of Acoustic-iconic Mnemonic Systems. Br. J. Ethnomusicology 9, 93-120. doi:10.1080/ 09681220008567302

Isola, A. (1982). Ena: Code Talking in Yoruba. J. West Afr. Languages 12 (1), 43-51.

King, A. (1961). Yoruba Sacred Music from Ekiti. Ibadan: Ibadan University Press.

Klein, D. (2000). Yoruba Bàtá: Politics of Tradition in Erin-Osun and Overseas. Santa Cruz: Diss. University of California.

Kubik, G. (2010). Theory of African Music, 2. Chicago and London: University of Chicago Press.

\section{ETHICS STATEMENT}

The studies involving human participants were reviewed and approved by Faculty Ethics Assessment Committee, Faculty of Humanities, Utrecht University. The patients/participants provided their written informed consent to participate in this study. Written informed consent was obtained from the individual(s) for the publication of any potentially identifiable images or data included in this article.

\section{AUTHOR CONTRIBUTIONS}

MG: First author, responsible for research design, field data collection, data analysis and redaction. OO: Second author: Responsible for field research organization, collaboration in data collection, help with data analysis and with article redaction.

\section{ACKNOWLEDGMENTS}

We would like to thank first and foremost our informants, Ayanlere Alajede, Kangan Bamidele and our bàtá master drummer, who opted to remain anonymous, for their kindness in sharing their art and knowledge with us, as well as Prof. Yoad Winter, for his insatiable curiosity and competent support. Finally, we thank the Dutch Research Council (NWO), for the financial support (project 360-89-060, "When language has a beat"), and Utrecht University, for being our home during this research.

Kubik, G. (2008). "Zur Mathematik und Geschichte der afrikanischen Time-Line Formeln," in Systematic and Comparative Musicology: Concepts, Methods, Findings. Editor A. Schneider (Frankfurt am Main: Lang), 359-398.

Lexicon of Linguistics (2021). Art. Intrinsic Characteristics. Available at: https:// lexicon.hum.uu.nl/?lemma $=$ Intrinsic + characteristics \&lemmacode $=1223 \&$ lemma $=$ IntrIntri+characteristics\&lemmacode $=1223$ (Accessed 0108,2021 ).

Olaniyan, O. (2008). The Manifestation of the Poetic Aptitude of the Yoruba Dundun Master Drummer within the Framework of Dundun Music. Awka J. Res. Music Arts 5, 95-110.

Olatunji, M. (2017). “A Historiographical Study of Gudugudu Drum - A Member of Dundun Ensemble in Yorubaland," in Musical Horizons in Africa (Essays and Perspectives): A Festchrift in Honour of Daniel Chikpezie Christian Agu (Ile-ifé: Association of Nigerian Musicologists), 247-253.

Olatunji, M. (2012). Yorùbá Proverbs and Musicality. Legon J. Humanities 23, $125-140$.

Oludare, O. E. (2020). “The Musical and Cultural Leadership Roles of Yoruba Master Instruments," in Governance and Leadership Institutions in Nigeria. Editors E. Aniche and T. Falola (London: Routledge), 65-74. doi:10.4324/ 9781003111405-7

Oludare, O. E. (2021). "Yoruba Traditional Instrumental Ensemble and Indigenous Knowledge Systems," in Pathways to Alternative Epistemologies in Africa. Editors A. Afolayan, O. Yacob-Haliso, and S. O. Oloruntoba (Cham: Palgrave Macmillan), 205-219. doi:10.1007/978-3-030-60652-7_12

Oludare, O. E. (2018). "Yoruba Traditional Musical Instruments and Gender Stereotyping: Forms, Functions and Factors," in Fela After 1997: Challenges, Justification and Lessons for Africa's Development (Ibadan: Global Image Publishers), 181-202.

Oluga, S., and Babalola, H. (2012). Drummunication: The Trado-Indigenous Art of Communicating with Talking Drums in Yorubaland. Glob. J. Hum. Soc. Sci. Arts, Humanities 12 (11), 38-48.

Omojola, B. (2012). Yoruba Music in the Twentieth Century: Identity, Agency, and Performance. Rochester, NY: University of Rochester Press. 
Ong, W. (1982). Orality and Literacy: The Technologizing of the Word. London and New York: Routledge.

Orie, O. O., and Pulleyblank, D. (2002). Yoruba Vowel Elision: Minimality Effects. Nat. Lang. Linguistic Theor. 20 (1), 101-156. doi:10.1023/a: 1014266228375

Osundina, O. (2015). Dundun: The Talking Drum of the Yoruba People of Southwest Nigeria. London: Austin Macauley Publishers.

Oyelami, M. (1991). Yorùbá Bàtá Music: A New Notation with Basic Exercises and Ensemble Pieces. Bayreuth: Iwalewa Haus.

Oyelami, M. (1989). Yoruba Dundun Music: A New Notation with Basic Exercises and Five Yoruba Drum Repertoires. Bayreuth: Iwalewa Haus.

Pulleyblank, D. (2004). A Note on Tonal Markedness in Yoruba. Phonology 21, 409-425. doi:10.1017/s0952675704000326

Ruskin, J. (2013). Diss the Yorùbá Dùndún in Local and Transnational Perspective: A Cosmopolitan Tradition in the Making. Los Angeles: Diss. University of California.

Sachs, C., Hornbostel, V., and Moritz, E. (1986). "Systematik der Musikinstrumente. Ein Versuch," in Tonart und Ethos: Aufsätze zur Musikethnologie und Musikpsychologie (Leipzig: Reclam).
Villepastour, A. (2010). Ancient Text Messages of the Yorùbá Bàtá Drum: Cracking the Code. Farnham: Ashgate.

Conflict of Interest: The authors declare that the research was conducted in the absence of any commercial or financial relationships that could be construed as a potential conflict of interest.

Publisher's Note: All claims expressed in this article are solely those of the authors and do not necessarily represent those of their affiliated organizations or those of the publisher, the editors, and the reviewers. Any product that may be evaluated in this article, or claim that may be made by its manufacturer, is not guaranteed or endorsed by the publisher.

Copyright $\odot 2022$ González and Oludare. This is an open-access article distributed under the terms of the Creative Commons Attribution License (CC BY). The use, distribution or reproduction in other forums is permitted, provided the original author(s) and the copyright owner(s) are credited and that the original publication in this journal is cited, in accordance with accepted academic practice. No use, distribution or reproduction is permitted which does not comply with these terms. 